\title{
GUIDE TO THE INTERNATIONAL ARCHIVES AND COLLECTIONS AT THE IISH: SUPPLEMENT OVER 2000*
}

In 2000 a new edition of the 'Guide to the International Archives and Collections at the IISH, Amsterdam' (henceforth cited as GIA) was published. This new edition differs from the 1989 edition by Atie van der Horst and Elly Koen in the following respects: summaries of documentation collections are inserted with the summaries of the other archives and papers (to be distinguished from these by a clause like 'collection of documents', or 'documents collected by'); collections on subjects have a chapter of their own now, next to the chapters 'Persons' and 'Organizations', and in a separate chapter there are summaries of papers, archives, or collections which are preserved in other institutions, but of which the IISH holds reproductions, mostly in the form of microfilms or microfiches.

As to the summaries the following components can be discerned:

I. Access. As a rule consultation is not restricted; any restrictions are indicated by *

2. Name. Names of persons include dates of birth and death when known. In the case of international organizations with names in more than one language, the name chosen corresponds to the language in which most of the documents were written. Among organizations that have changed their names, the one used most recently was selected. Previous names of organizations are mentioned in the condensed biography or history. The names of subject collections are mostly in English.

3. Period. First and last date of the documents present. Where only a few documents are from a certain year or period, they are listed between parentheses.

4. Size. In linear metres.

5. Finding aid. Available inventories (published and unpublished), lists and indexes.

6. Biography/history. A condensed biography or history of the persons or organizations concerned.

7. Summary of the contents. A summary of the contents of the archives, papers or collection concerned.

Reference is given to the pages of the GIA holding the initial description where summaries of an accrual are concerned.

The summaries of this supplement will also be added to the survey of archival collections on the Internet website of the IISH (http://www.iisg.nl). Summaries of the Dutch collections of the IISH can be found in the survey on the Internet website too.

The archives may be consulted in the reading room of the IISH. Requests for documents should include their inventory or list numbers. For further information about the rules for access and consultation, (including rules on procedures for

* Edited by Jaap Haag. 
handling the material and making photocopies) users should contact the information service of the IISH (e-mail: vid@iisg.nl).

\section{Persons}

\section{*Althans, Bernd Ewald (Bela) (born 1966) Period: 1980 s and 1990 s}

\section{Size: c. $45 \mathrm{~m}$.}

Born in Bremen, Germany 1966; in his youth for a short time member of Aktion Sühnezeichen, but, while still a gymnasium pupil in Hannover, switched to the extreme Right; participated in paramilitary training of the Wehrsport but broke away with some friends to found the Nationale Jugend Deutschlands; expelled from school and the parental home, he joined the Deutsche Freiheitsbewegung der Bismarck-Deutsche of the former SS-major, Otto Remer; in 1983 he became a member of the neo-Nazi organization, Aktion National Sozialisten (ANS) headed by Michael Kühnen; after his rupture with Kühnen at the end of the I980s he became friends with Ernst Zündel, a 'revisionist' publisher who denied the Holocaust; organized the conference 'Wahrheit macht Frei' 1990; broke with neo-Nazism in 1992, partly because of his aversion to the attacks/assaults on refugees and other foreigners in Germany, partly because of his bisexuality; main figure in Winfried Bohnengel's documentary movie 'Beruf Neonazi'; sentenced to a three-and-a-half year term in 1995 for incitement and his denial of the Holocaust in earlier years; left Germany after his release.

Prison diaries; correspondence with neo-Nazi organizations in Europe, the USA and South Africa; address lists; documents on trials; pamphlets; illegal facsimile editions of publications of Joseph Goebbels and other documents.

\section{*Ammers-Douwes, Jeanne J. van (born 1944) \\ Period: $1983-1999$ \\ Size: $0.4 \mathrm{~m}$.}

Born in Zaandam, the Netherlands I944; from 1974 active member of the group Midden-Betuwe of Amnesty International Nederland; on behalf of this group corresponded with Gatot Lestaryo, an imprisoned party leader of the Partai Komunis Indonesia (PKI); being arrested in 1969, Gatot Lestaryo was condemned to death in 1976 and executed in 1985; the Amnesty International group Midden-Betuwe continued its correspondence with other political prisoners in Indonesia, including Muslim militants.

Correspondence with Gatot Lestaryo and his son Pradono I984-I985; correspondence and other documents relating to the trials against and the imprisonment of Hartono Rekso Dharsono, Andi Mappetahang Fatwa, Kartini, Soewarno Manuk, Ali Masrum, Pudjo Prasetio, Johannes Sucipto, Tri Agus Susanto, Djoko Untung and other political prisoners in Indonesia 1983-1995; documents concerning the illegal flag-raising ceremony by Papuans in Jayapura, Irian Jaya on 44 December 1988, the subsequent imprisonment of about sixty persons and, in particular, the case of Marthinus Marani I988-I994; documents relating to the illegal Partai Rakyat Demokratik (PRD; People's Democratic Party) i996-ı999.

\section{Baudert, F. August (I860-1942)}




\section{Period: I 868-I9I I}

\section{Size: $0.02 \mathrm{~m}$.}

Born in Apolda, Germany I 860, died in Oranienburg, Germany 1942; member of the council of Apolda for the Sozialdemokratische Partei Deutschlands (SPD) I892-1906; SPD secretary in Weimar 1906-1914; member of the Landestag Sachsen-Weimar I894-1920, and the Landestag Thüringen I920-I92I; member of the Reichstag I898-I907, I912-I920.

Letters (copies) concerning the social democratic movement in Thüringen from Wilhelm Bock, Wilhelm Fink, Bruno Geiser, Julius Motteler, Hermann Sy and others to August Baudert and Al. Müller i868-i9i I.

\section{* Bourseiller, Christophe (born I957) \\ Period: 1996-1999 (copies from 1960) \\ Size: $0.3 \mathrm{~m}$.}

Born in Paris 1957; writer, actor and journalist, studied left-wing parties, cultural avant-garde and counter-cultures, published a dozen books on the Trotskyist movement, the theories of the Internationale Situationiste, Maoists in France and Messianic movements; played as a film actor in several films by Jean-Luc Godard and others.

Files regarding his publications 'Les Maoïstes: la folle histoire des gardes rouges français', 'Cet étrange monsieur Blondel: enquête sur le syndicat Force Ouvrière', and 'Vie et mort de Guy Debord'; correspondence and other documents regarding his research for these and other publications, including copies of correspondence by Guy Debord with various persons (I960) I996-I999.

\section{* Gibson, Tony \\ Period: 1977-1998 \\ Size: $0.15 \mathrm{~m}$.}

British anarchist; as a BBC producer of programmes on youth groups and social workers, interested in action groups in local communities and neighbourhoods; head of the Department of Psychology at Hatfield Polytechnic; author of 'People Power: community and work groups in action', 1979, of 'Kindling the Phoenix Nest. Interviews with pioneers of anarchism in post-war Britain', and of publications on the emotional and sexual lives of older people.

Correspondence and some transcriptions of his interviews with Cyril Cannon, Nicholas Comfort, Rudolf de Jong, Sid Parker, Vernon Richards, Donald Rooum, Harold Sculthorpe, Rufus and Sheila Segar, Jack and Mary Stevenson, Colin Ward, George Woodcock, and others 1977-1998; other documents relating to his research for 'Kindling the Phoenix Nest. Interviews with pioneers of anarchism in post-war Britain'.

\footnotetext{
* Gómez Peláez, Fernando (I91 5-1995)

Period: 1973

Size: $0.04 \mathrm{~m}$.

Accrual: for biography see GIA p. 93.
} 
Stencilled typescript of 'La muerte de la vergüenza' written by J. García Pradas in I973 in response to 'La muerte de la esperanza' by Eduardo de Guzmán.

\author{
Gontarbert, Sania (1916-2000) \\ Period: 1939-1998 \\ Size: $1.25 \mathrm{~m}$.
}

Born in Odessa, Russia 1916, died in Paris, 2000; pseudonyms: Sylvain Gobert and Lucien Magneux; Trotskyist militant; lived in France since 1925 ; came in touch with left-wing ideas through his membership of the Centre Laïque des Auberges de Jeunesse; developed Trotskyist sympathies as a result of the Moscow trials and the Spanish Civil War; settled in Toulouse in July I940 after demobilization and became a member of the clandestine Parti Ouvrier Internationaliste (POI); moved to Lyons where he co-edited the clandestine Front Ouvrier, which after the liberation continued as the first legal Trotskyist periodical; within the Party, renamed Parti Communiste Internationaliste (PCI), he sided with the opposition against unconditional support for the USSR; after the split in 1948 he joined the movement Union Ouvrière Internationale, which split again; some of its former members, including Jean Malaquais and Serge Bricianer, formed a discussion group which published the Cabiers de discussion pour le socialisme des conseils.

Manuscript of a political diary covering the period I978-1997; typescript of memoirs 'Souvenirs éparpillés' c. 1982; biographical notes and typescripts by Gontarbert n.d.; leaflets and copies of Front Ouvrier and Fraternisation Prolétarienne, organ of the revolutionary communists I942-1944; documents on the PCI and its 1948 congress and leaflets issued by the PCI from I 944 onwards; documents on internal discussions within the PCI and the Fourth International on the 'Russian question' 1939-I95 I and on nationalism and colonialism 1945-1967; typed reports of the meetings of the discussion group with Serge Bricianer, Sania Gontarbert, Jean Malaquais, Ngo Van, Maximilien Rubel and others 1958-1968; documents regarding the preparation of 'Combats pour Marx', a book dedicated to Maximilien Rubel 1997; documents relating to the Rassemblement Communiste Révolutionnaire, including the file 'Notre Victoire. La Plateforme Programmatique des Communistes Révolutionnaires'.

\title{
* Hering, Bob (born 1925 ) \\ Period: 1919-1999 \\ Size: $2.5 \mathrm{~m}$.
}

Accrual: for biography see GIA p. I04.

Correspondence I99I-I999; documentation concerning the Dutch East Indies/ Indonesia I920S-I950s; minutes of the meetings of the municipal council of Batavia I9I9-I94I (copies).

\author{
Keating, Keven (born 1960) \\ Period: $1992-2000$ \\ Size: $0.12 \mathrm{~m}$.
}

Born in Washington DC, USA, I960; local activist in San Francisco; involved in several actions; 
collector of documents on the Mission Yuppie Eradication Project, a direct action campaign to safeguard the working-class character of the Mission area in San Francisco and to prohibit its change into an expensive yuppie neighbourhood 1998-1999; editor of the anti-Trotskyist The Poor, the Bad and the Angry. A magazine for Power-hungry Proletarians; produced on his own the movie 'The Ballad of a Green Beret'.

Leaflets, letters, (photocopies of) prints of short stories, clippings and other documents relating to the Mission Yuppie Eradication Project and other actions in which Keven Keating has been involved I992-1999; documents on The Poor, the Bad and the Angry. A magazine for Power-hungry Proletarians.

NB. A copy of his movie 'The Ballad of a Green Beret' has been transferred to the audiovisual department of the IISH.

\section{* Kolpinskij, Nikita Jur'evic (born I93 I) \\ Period: 1999-2000 \\ Size: $0.02 \mathrm{~m}$.}

Born in Losino-Ostrovskoe, Soviet Union 193 I; staff member of the former Institute of Marxism-Leninism (now Rossijskij Centr Chranenija i Izu čenija Dokumentov Novejšej Istorii (RCChIDNI)) in Moscow.

His memoirs, including his memories of the former Institute of Marxism-Leninism (IML) in Moscow (covering the period from about I940 to 1999), I999-2000.

\section{Krauss, Christiane \\ Period: 1977, 1995, 1999 \\ Size: $0.05 \mathrm{~m}$.}

Born in Athens; lived for many years in France; travelled through the People's Republic of China as a member of a delegation of the French Association des Amitiés Franco-Chinoise.

Documents relating to her visit of China in I977, including comments on slides made during her trip 1977, I999; printed material relating to the United Nations Fourth World Conference on Women in Beijing in I995.

NB. Slides collection has been transferred to the audiovisual department of the IISH.

\section{* Kurzke, Jan (1905-1981) and Mangan, Kate (1904-1977) Period: 1934, 1936-1937, 1998 \\ Size: $0.1 \mathrm{~m}$.}

Jan Kurzke (official name: Hans Robert Kurzke): born in Hamburg, Germany 1905; Marxist militant and painter; fled the Nazi regime in 1933 and found refuge in Spain; fought in the Spanish Civil War as a volunteer in the International Brigades; together with Kate Mangan, he left Spain for England in 1937, but during the Second World War they broke off their relationship;

Kate Mangan (maiden name: Katherine Prideaux Foster): born in Sedgley, Staffordshire, Great Britain 1904; artist, actress, journalist; married the Irish-American scholar, poet, writer and Trotskyist revolutionary, Sherry Mangan, I 93 I; divorced 1935 after meeting Kurzke in 1934; went to Spain to discover what happened to Kurzke 1936. 
Typescript of 'The Good Comrade', memoirs of both on their 'separate but connected' adventures in Spain, covering Kurzke's travel to Spain in I934 and his time as a member of the International Brigades I936-1937 and Mangan's travel through Spain searching for Kurzke 1936-1937; an introduction and explanatory notes to the typescript by their daughter Charlotte Kurzke and a letter from her to Harriet Ward on the history of her family 1998.

\section{* Mosolov, Vladimir Gavrilovič (born 1932) \\ Period: 1999-2000 \\ Size: $0.01 \mathrm{~m}$.}

Accrual: for biography see GIA supplement over 1999 p. 368 .

Typescript of the first part of 'Materials on the history of the Institute of MarxismLeninism (IML)' in Moscow (covering the period from I92 I to I930) I999-2000.

\section{Rahman, Md. Mahbubar (born 1952)}

Period: 1994-2000

Size: $0.02 \mathrm{~m}$.

Accrual: for biography see GIA p.I78.

Leaflets, cards, and other printed documents of political organizations in Bangladesh I 994-2000.

\section{Sayed, Ghulam M. (1904-1995)}

Period: 1928-1985 (-1996)

Size: $0.36 \mathrm{~m}$.

Accrual: for biography see GIA p.196.

Correspondence by Sayed and others I928-1968; documents relating to the Sindh Legislative Assembly 1937, 1943, I953-1954; the Sindh Assembly Coalition Party 1946; the National Awami Party 1955-1958 and other political organizations; documents on Hindu-Muslim relations in Sindh I928-1940; documents concerning Sayed's detention 1970-1971 and on subsequent restrictions 1972-1985; copies of articles, some of them by Sayed i929-1996.

\section{Schwalba-Hoth, Frank (born 1953) \\ Period: 1983 \\ Size: $0.12 \mathrm{~m}$. \\ Finding aid: preliminary list}

Born in 1953; studied in Marburg, Germany; president of the Marburg student parliament (?) 1979-1980; member of the parliament of the federal state of Hessen for the Grüne Partei from 1982; elected to the European Parliament in 1984; by way of an antimilitarist protest Frank 
Schwalba-Hoth sprinkled the uniform of US general Paul S. Williams with blood during a reception in the Hessen Parliament in honour of the commanders of the US Army forces in Hessen on 3 August 1983 .

Collection of c. 470 letters sent to the fraction of the Grüne Partei in support of, or criticizing, the protest action of Frank Schwalba-Hoth and other material used for the Grüne Partei pamphlet Die Würde einer Uniform ist antastbar. Eine Dokumentation 1983.

\section{Sheel, Ramesh (died 1967) \\ Period: 1944, I946, I951-I953, I964 \\ Size: $0.01 \mathrm{~m}$.}

Born in the Chittagong district of Bangladesh at the end of the nineteenth century, died at the same place 1967; reciting poet or 'kobial', who improvized his poems while singing; joined the IPTA, the cultural organization of the Communist Party of India; introduced the element of class conflict in the kobir lorai, a traditional performance of two contesting kobials.

Some manuscripts of poems I944, I946, I95 I-I953; leaflet on the homage of Ramesh Sheel in 1964 .

\section{* Sitnina, Marija Ksenofontovna (I910-2000) Period: n.d.}

Size: $0.02 \mathrm{~m}$.

Born in Naro-Fominsk, Russia 1910, died in Moscow 2000; art historian.

Her memoirs (covering the period from I926 to I95I) and biographical outlines of artists.

\section{* Smit, Ferdinand (1959-2000) \\ Period: (1971-) 1979-2000 \\ Size: c. $3 \mathrm{~m}$.}

Born in Leiden, the Netherlands 1959; studied archeology and Arabic at the Universities of Amsterdam and Leiden; served as an interpreter and information officer of the Dutch UNIFIL battalion, which was camped in the south of Lebanon as part of a United Nations interposition force after the Israeli invasion in 1982; entered the Netherlands Foreign Service and was sent out to Cairo and Damascus; worked at the office of the UN Special Coordinator in Gaza, Palestine 1996-1999; tragically killed in 2000 while on a tour in Mali; his thesis on the radicalisation of Lebanon's shi'ites and the rise of the Hezbollah was published posthumously.

Collection of documents used for his thesis 'The Battle for South Lebanon. The Radicalisation of Lebanon's Shi'ites I982-1985' consisting of files on Dutch foreign policy in the Lebanon and the Middle East, and on the position of the Dutch UNIFIL battalion, including documents of its Military Information Section and copies of minutes of meetings at the UNIFIL Headquarters in Naqura 1979-I992; reports of the Foreign Broadcast Information Services (FBIS) I980-198I; photocopies of scholarly publications I97I-I999 and press clippings from Lebanese, Israeli, and 
other newspapers I98 I-I998; some personal documents, including drafts of his thesis and correspondence on his doctorate 1996-2000.

\section{Soerjono (1928-2000) \\ Period: $1960-2000$ \\ Size: $0.5 \mathrm{~m}$. \\ Finding aid: inventory}

Born in Prambanan, Java, Dutch East Indies (Indonesia) 1928, died in Amsterdam 2000; journalist; primary education at the Hollandsch-Indische School (HIS); studied at the Cultuurschool, an agricultural secondary school; during the Japanese occupation arrested and sentenced to a nearly two-year term of imprisonment for the illegal spread of Menara Merab (Red Tower); one of the founders of Angkatan Muda (Young Generation), from which the Pesindo (Pemuda Sosialis Indonesia; Socialist Youth of Indonesia) originated; from 1945 journalist of the Pesindo daily Penghela Rakjat and its weekly, Revolutioner, and from 1948 of the daily Harian Rakjat (later the organ of the Partai Komunis Indonesia (PKI)); editor-in-chief of Sport E Film, weekend edition of the Harian Rakjat 1959-1964; posted to China as correspondent for the Harian Rakjat in 1964; left China in 1972 and, unable to return to Indonesia without risk, went to the Soviet Union; came to the Netherlands in 1989 with the help of Dutch friends; wrote his memoirs and worked on books on Soedisman and on Amir Sjarifoedin which remained unpublished.

Diaries I968-1969, I990; letters from his brother Alex S. Soenarjo I990-1996 and other correspondence 1967, I977, I986-2000; financial documents 1965, 1989-1990, I993, I997; identity papers and other personal documents I960-1963, I987, I989I990, I999 and n.d., including a photocopy of his membership card of Madjelis Permusjawaratan Rakjat Sementara (MPRS); manuscript of his autobiography 'Van Moskou zonder liefde, een autobiografie zonder pretentie' c. I990; typescript of 'Soedisman. The Organisator and "the King Maker" that Failed' i 985 ; manuscripts of a book on Amir Sjarifoedin and of articles I 995 and n.d.; transcriptions of audiotapes of an interview by Kees Princen with Soerjono I992-I993 and n.d.; report by Sudomo on the PKI and other documentation on Indonesia and Russia 1978, I988I 996, I 999 and n.d.; printed articles concerning Soerjono I 994, 2000 and n.d.

\section{Organizations}

\section{All Burma Students' Democratic Front (ABSDF) \\ Period: $1988-2000$ \\ Size: $0.6 \mathrm{~m}$. \\ Finding aid: list}

Accrual: for initial description see GIA supplement over I999 p. 369.

Reports of and other documents relating to meetings of the Central Committee and the Central Executive Committee 1990-1996; documents relating to conferences of the ABSDF I99I-I996; documents on the political and military policy of the ABSDF; orders by the ABSDF headquarters I990-1997; statements; documents on the organization of the ABSDF, including the financial and health care departments; documents on refugees, the Rodhengar problem, women, human rights violations, the 
SLORC and other subjects; copies of research papers and other publications by the ABSDF Documentation and Research Centre; news bulletins of the Democratic Voice of Burma (DVB) 1992-1999; printed material.

\author{
Communist Party of India (Marxist Leninist) (CPI (M-L)) \\ Period: c. $1996-1998$ \\ Size: $0.02 \mathrm{~m}$. \\ Accrual: for initial description see GIA p. 255 .
}

Leaflets and other printed documents of the Communist Party of India (MarxistLeninist) (CPI (M-L)), the CPI (M-L) Liberation and other communist organizations in the Indian federal states West Bengal, Assam and Bihar.

\title{
Federación Española de Deportados e Internados Políticos (FEDIP) Period: $1945-1973$ \\ Size: $2.12 \mathrm{~m}$.
}

Accrual, including documents from José Ester Borras: for initial description see GIA p. $27 \mathrm{I}$. Ester Borras, José: born in Berga, Spain I913, died in Alès, France 1980; trade unionist and campaigner for political prisoners; active in the Spanish anarchist youth movement; fought in the Colonna Tierra y Libertad during the Spanish Civil War; was arrested by the communists; fled to France in 1939; participated in the French resistance against the Nazis; was arrested and deported to the concentration camp Mauthausen; returned to France in 1945; as one of the founders and moving spirit of FEDIP, Ester campaigned for political prisoners in Franco's Spain, for former political prisoners in German concentration camps, and for imprisoned Spanish republicans in the Soviet Union; also active in the Confederación Nacional del Trabajo (CNT) in exile.

FEDIP: minutes and other documents of meetings and congresses 1945, I96I, I965, 1967, 1970-1973; statutes and rules 1945, 1970; lists of sections n.d.; financial notes I960-I96I; correspondence and other documents concerning the campaign for the release of the Spanish prisoners in Karaganda 1947-1956; correspondence with F. Herzfelder, Felix Martorell, Carlos Martinez Parera, and others concerning indemnity payments to former Spanish prisoners in German concentration camps 1958-1974; other documents on indemnity payments, including documents concerning the German Bundesentschädigungsgesetz ( BEG) I954-I 974 and n.d.; reports and notes by Hans Marsalek and others concerning former Spanish prisoners in Mauthausen 1949, I953, I957-1971, I978 and n.d.; lists of names I946, I 968 and n.d.; documents concerning the Fédération Nationale des Déportés et Internés Résistants et Patriotes (FNDIRP) 1968-1970 and n.d.; documents concerning the Fédération Internationale Libre des Déportés et Internés de la Résistance (FILDIR) 1964-1965, 1970 and n.d.; other documents and clippings concerning deported Spaniards in German concentration camps 1939-1940, 1946-1972 and n.d.

José Ester Borrás papers: personal correspondence 1937, I939-1952, 1957-1961; identity cards and other personal documents I93 I, 1937, I945-1947, I952 and n.d.; typescript of 'Recuerdos y Reflejos', first chapter of his autobiography 1942; documents on the French resistance and the liberation of Paris 194I, 1945-1946, I948, I959, I 966 and n.d.; documents from his wife Odette Ester-Kervorc'k I976- 
I 992 and n.d.

CNT in exile: minutes of meetings I948-1949; correspondence with A. Germinal Esgleas of the Movimiento Libertario Español (MLE) I947-I948 and correspondence with Marcelino Massana i95I-1952, José Peirats I95I and n.d., Roque Santamaria I95I-I952 and others 1945-1974; files concerning persons, including Juan Cazorla Pedrero 1952-I954; Luis Companys 1934, I936, I940, I969-1970; Guillermo Farregut Castells I950 and n.d.; A. Florentino Estallo I952-I955; Gabriel Garcia Tomas I949-1950; Manuel Mendez de Vigo y Cubas n.d.; Quintin Sanchez I952; Francisco Sanz I950 and n.d.; Felipe Torrente Larrosa I952-I953; files on the weekly Ruta of the Federación Ibérica de Juventudes Libertarias (FIJL) in France I953, on interventions in behalf of prisoners in Spain and France 1946-1947, 1949, I952, on the exile of inhabitants from Berga in France 1947-I95I-I953, I957-1960, I966 and other subjects; reports, notes and other documents concerning the CNT 1946-1952, I966 and n.d.; typescripts of articles by J. Ester 194I, I943; printed material, including photocopies of newspaper articles by Albert Camus on the Franco regime in Spain 1948-1953, I957, I959, I961-1962, I964-1966 and n.d.

\section{Gulf Peace Team \\ Period: $1990-1992$}

\section{Size: $\mathbf{I}$ m.}

The Gulf Peace Team was an international organization aiming at peace and justice in the Middle East through nonviolent means; headquarters in London and Amman, Jordan; activities were the issuing of a newsletter and the organizing of peace walks in the Middle East.

Documents regarding peace walks from Jericho to Jerusalem I99 I and the 'Walk for a peaceful future in the Middle East' in Israel/Palestine I992; documents regarding other activities I990-I 992.

\section{Initiativgruppe Peter-Paul Zahl \\ Period: $1977-1980$ \\ Size: $0.1 \mathrm{~m}$. \\ Finding aid: list}

German action group; originated in the second half of the I970s; tried to reopen the case of PeterPaul Zahl, who was sentenced to fifteen years imprisonment for wounding a police officer in a gunfight in 1972; Zahl (born in Freiburg, Germany 1944) had settled in West Berlin to escape military service; he was a member of the Neue Linke and Gruppe 6r; started the publishing house Peter Paul Zahl in 1967 , issuing the literary journal Spartacus and the series p.p. quadrat; sentenced to a half-year term because of the publication of the pamphlet Freibeit für alle Gefangenen in 1970; during his second period of imprisonment Zahl published several novels, poems, and essays, and in 1980 he was awarded the literary prize of the city of Bremen for his novel 'Die Glücklichen'; in the same year he was transferred to the prison in Berlin-Tegel, where he was allowed to work at the Schaubühne in Berlin; released in 1982 ; emigrated to Jamaica 1985.

Signature lists, demanding the reopening of the case and the release of Peter-Paul Zahl; correspondence by Lutz Eisel and Heinrich Hannover, the lawyers of Zahl, with the judicial authorities; a diary, letters and other texts, written by Zahl in prison I977-1980. 


\author{
International Sociological Association (ISA) \\ Period: 1962-1995 (-1998) \\ Size: $0.8 \mathrm{~m}$. \\ Accrual: for initial description see GIA p. 292.
}

Correspondence and newsletters by Research Committees I974-I995 (-1998); minutes of meetings of the Executive Committee 1962-1994; correspondence by the Executive Committee 1982-1990; minutes of meetings of the Membership and Finance Committee 1988-1994, the Program Committee 1968-1993, the Publications Committee I975-1994 and the Research and Coordinating Committee 1976I994; reports of the meetings of the Research Council I974-I994 and of the National Associations meetings 1970- I994; documents relating to regional conferences I974I977; documents on the United Nations 1975-1995 and the World Health Organization (WHO) I974-I99I; documents from president Ulf Himmelstrand I979-I982; membership list I976-I992; clippings I968-i995 and other documents.

\author{
International Union of Socialist Youth (IUSY) \\ Period: $1965-1969$ \\ Size: $0.01 \mathrm{~m}$. \\ Accrual: for initial description see GIA p. 296.
}

Additional documents from Walther (Euregionales Freizeit- und Informationswerk für Jugendarbeit e.V.) i965-I969.

\title{
* National Democratic Front (NDF) \\ Period: $198 \mathrm{I}-\mathbf{I 9 8 8}$ \\ Size: $0.2 \mathrm{~m}$.
}

Originated in 1971, when nine representatives of different social groups of Philippine society convened as the NDF Preparatory Committee (Prepcom); the NDF is an alliance of various revolutionary groups in the Philippines, aiming at social justice, democracy and progress; the NDF has an international office in Utrecht, the Netherlands, which is headed by José Maria Sison, founding chairman of the Partido Comunista de Filipinas.

Collection consisting of press releases, some correspondence, texts of speeches by José Maria Sison, and other documents from the National Democratic Front International Office in Utrecht, the Netherlands I989, I99I-I999; notes, conference papers, copies of periodicals and other printed material relating to revolutionary organizations in Asia, including the Communist Party of the Philippines (CPP) and the Japan Labor Party i98 I-i 988.

\author{
Partai Rakyat Demokratik (PRD, People’s Democratic Party) \\ Period: I99I-I 999 \\ Size: $0.6 \mathrm{~m}$.
}

Indonesian left political party; founded formally at a congress in April 1996; the PRD had 
previously existed as the Peoples Democratic Union, which was established in 1994; the PRD promotes the importance of the mass movement and extra-parliamentary forces in challenging the Indonesian regime.

Collection of leaflets, reports, statements on the PRD I990s; some periodicals among others Suara Burub I993; documents concerning student actions I99I-I998; PRD documents on the elections 1997; documents concerning the students organisation Solidaritas Mahasiswa Indonesia untuk Demokrasi (SMID); propaganda material.

\section{Subjects}

\section{Burma political and social movements \\ Period: 1961, 1980-1998}

Size: $0.24 \mathrm{~m}$.

From 1974 the military, in power ever since 1962, ruled Burma (Myanmar) through the mechanism of the Burma Socialist Programme Party (BSPP); in 1988 mass calls for democracy met with severe repression by the armed forces, which was accompanied by much bloodshed; bowing to international pressure the regime held general elections in 1990 but refused to recognize the victory of the oppositional National League for Democracy (NLD); continued repression involved the arrest and detention of thousands of supporters of democracy, denial of freedom of speech, assembly and association, and violence against ethnic minorities.

Collection consisting of documents relating to the BBC Burmese Services I98 I, I988; a typescript on the history of the $\mathrm{Pa}-\mathrm{O}$ people by a group of anonymous authors [1990]; notes and other documents concerning the author Ma Ma Lay (I917-I982), used for an introduction to the English translation of her novel 'Not out of hate' I96 I, I980, I982, I986; papers of the Conference on Myanmar Culture and Society at the Chulalongkorn University in Bangkok 1998; copies of periodicals and clippings on the 1988 repression and other subjects, including prints of the results of the 1990 elections 1983-1985, I988-I993, I995.

\section{Hungarian labour booklets}

\section{Period: 1915-1950}

Size: 0.02

On the basis of a law of I 886 every labourer should dispose of a workman's passport which had to be filled in and stamped by the employer in case of every mutation.

Collection of eleven labour books of Hungarian labourers during the period igisI950.

\section{Hungarian Republic of Councils \\ Period: 1918-1919 \\ Size: $0.12 \mathrm{~m}$.}

Accrual: for initial description see GIA p. 366.

Clippings concerning the Hungarian Republic of Councils. 


\section{* Nationalist movement in Arakan \\ Period: 193 I, 1994, 1996, 1998 \\ Size: $0.02 \mathrm{~m}$.}

Accrual: for initial description see GIA p. 370 .

Appeals to the government of India, statements and press releases of the Arakan (Rakhaing) League for Democracy (ALD) and the National United Party of Arakan (NUPA) on the fate of seventy-three freedom fighters of the NUPA-Arakan Army (AA) arrested by the Indian military forces 1998; some other documents, including a statement by Ottama Bhikkhu I93 I.

\section{Progressive movements in Pakistan \\ Period: (192 I-) 1947-2000 \\ Size: $\mathrm{I} .6 \mathrm{~m}$. \\ Finding aid: list}

Accrual: for initial description see GIA p. 372.

A series of chronological notes on the political history of Pakistan by Ahmad Saleem 1947-1969, 1971-1977; a series of documents relating to political parties and politicians collected by Ahmad Saleem, including his supplementary notes 19471969, I97 I- 1977; congress papers, manifestos, leaflets, newsletters, copies of periodicals and other documents relating to the Communist Party of Pakistan (CPP) I975, I98 I-1988, I999-2000, the East Pakistan Awami League 1966, I969, the Kalat State National Party 1947, the Labour Party Pakistan 1998-2000, the Mazdoor Kisan Party (MKP) 1972-1975, the Communist Mazdoor Kisan Party (originated from a merger with the CPP) 1998-2000, the National Awami Party 1966-1970, the Pakistan Peoples Party (PPP), I970-1974, I987-1988, 1990, 1992, I994, the Pakistan Socialist Party 1988-1999, the Young Peoples' Front 1970-1973 and other political organizations; documents relating to trade unions, the student movement and the peasant movement; booklets, pamphlets and other printed material, including the secret 'Punjab political Who's Who' I92 I and a series of government intelligence reports on the 1947 massacres of Muslims (published in 1948); personal documents consisting of manuscripts of poems by Sara Shagufta, a manuscript by Iqbal Leghari on the history of the socialist movement in Pakistan, an autobiographical account by Fazal Ilahi Qurbun, some documents of Hyder Baksh Jatoi 1968- I 969, documents of S.M. Jaffar, Director of Archives of the North-West Frontier Province 1931, 1935-1974 and director of the Peshawar Museum, consisting of correspondence with historians, librarians, and others 1964-1973; completed questionnaires and other documents.

\section{Protest movements in Bangladesh \\ Period: c. 1990 s \\ Size: $0.12 \mathrm{~m}$. \\ Finding aid: list}

Accrual: for initial description see GIA p. 373 .

Documents collected by Shahriar Kabir consisting of leaflets, pamphlets and some 
other documents of the Bangladesh Sammyobadi Dal (M-L) (Communist Party of Bangladesh (Marxist-Leninist)), the National Awami Party, the Sramik Krishok Samajbadi Dal and the Bangladesh Workers' Party.

\section{Tapols (Indonesian political prisoners) \\ Period: $1987-1998$ \\ Size: $0.25 \mathrm{~m}$.}

Collection of memoirs and autobiographies by Indonesian tapols (tahanan politik, expolitical prisoners), among others Yeni Rosa Damayanti, Harini Asmu, Ibu Harlinah, Ir. Iskandar, Abdul Latief, Hasan Raid, Sam, Suljana, Ibu Sulami, Supratig and Tri Agus Susanto Siswowihardjo 1987-1998; report on the Cipinang prison in Jakarta by Asep Suryaman 1998.

\section{Reproductions}

Jewish Labor Committee (JLC)

Period: $1934-1947$

Size: 2 reels

Finding aid: list

Accrual: for initial description see GIA p. 4 I2.

Additional documents, including delegate cards to the JLC founding convention I934-I947.

NB. Originals at the Robert F. Wagner Labor Archives, New York.

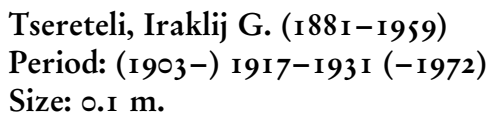

Born in Gorisa, Georgia, Russia I88I, died in New York USA 1959; Menshevik politician; studied in Moscow 1900-1902; exiled to Siberia 1902-1903; elected to the second Duma in 1907 but soon after again sentenced to exile in Siberia; member of the Petrograd Soviet and the provisional government in 1917; elected to the Constituent Assembly, he escaped to Georgia after its dispersion by the Bolsheviks in 1918; Georgian representative at the Paris Peace Conference in 1919; lived in France until 1948, when he left for the USA.

Collection of processed documents used by W.H. Roobol for his biography of Tsereteli consisting of some correspondence 1922-1931; articles by Tsereteli 1928I93 I and n.d.; publications by others and some other printed material 1903, I9171919, 1930, I961, I972 and n.d. 